\title{
Pengaruh Gaya Belajar Siswa terhadap Hasil Belajar Pendidikan Agama Islam
}

\author{
Siti Rafika Sari, Arief R, Nursaeni \\ Prodi Pendidikan Agama Islam, IAIN Palopo \\ Email: rafiqaiain@gmail.com
}

\begin{abstract}
Research aims to understand a style learning and study results style and influence in the learning student learning islamic education $x$ a state sma palopo 4. Type this study quantitative with the design ex-post facto capital with a population of 51 students with the sample is covering sampling.Data drawn through the survey data processed by analysis descriptive statistics and statistics inferential.The research results show that study visual style, auditory, students and a kinesthetic having influence in the the highest student learning study visual style of 13,2\%.Religious education study results people in the 28 people and frequency the $55 \%$ the percentage.And influence the style of student learning islamic education in the learning supported by $r^{2}$ ( $r$ square) of 0,360 or $36 \%$ style learning in the learning student effect for islamic education.
\end{abstract}

Keywords: Learning styles, learning outcomes, islamic education

\begin{abstract}
Abstrak
Penelitian ini bertujuan untuk mengetahui gambaran gaya belajar dan hasil belajar serta pengaruh gaya belajar siswa terhadap hasil belajar pendidikan agama Islam di kelas X SMA Negeri 4 Palopo. jenis penelitian ini kuantitatif dengan desain ex-post facto dengan jumlah populasi adalah 51 siswa dengan pengambilan sampel meliputi sampling. Data diambil melalui angket data diolah dengan analisis statistik deskriptif dan statistik inferensial. Hasil penelitian menunjukkan bahwa gaya belajar visual, auditori, dan kinestetik siswa memiliki pengaruh tertinggi terhadap hasil belajar siswa yaitu gaya belajar visual sebesar $13,2 \%$. Hasil belajar pendidikan agama Islam dalam kategori baik dengan frekuensi 28 orang dan hasil persentase $55 \%$. Adapun pengaruh antara aspek gaya belajar siswa terhadap hasil belajar pendidikan agama Islam didukung oleh koefisien $\mathrm{R}^{2}$ ( $\mathrm{R}$ Square) sebesar 0,360 atau $36 \%$ gaya belajar siswaberpengaruh terhadap hasil belajar pendidikan agama Islam.
\end{abstract}

Kata Kunci: Pengaruh, Gaya belajar, Hasil Belajar, Pendidikan Agama Islam.

\section{Pendahuluan}

Secara teoritis gaya belajar memegang peranan penting dalam hubungannya dengan hasil belajar. Seperti yang di kutip oleh Bobbi di kutip DePorter dan Mike Hernacki dalam bukunya Quantum Learning, gaya belajar merupakan kunci untuk mengembangkan kinerja dalam pekerjaan, sekolah, dan dalam situasi antar pribadi sehingga gaya belajar memengaruhi 
seseorang dalam menyerap dan mengolah informasi sehingga akan memengaruhi prestasi yang dicapai. ${ }^{1}$

Berdasarkan uraian tersebut, dapat dikemukakan bahwa gaya belajar adalah kombinasi dari menyerap, mengatur, dan mengolah informasi. Terdapat tiga jenis gaya belajar berdasarkan modalitas yang digunakan individu dalam memproses informasi (perceptual modality) yaitu sebagai berikut :

a. Gaya Belajar Visual (Visual Learners) menitikberatkan pada ketajaman penglihatan. Artinya, bukti-bukti konkret harus diperlihatkan terlebih dahulu agar mereka paham. Gaya belajar seperti ini mengandalkan penglihatan atau melihat dulu buktinya untuk kemudian bisa mempercayainya.

b. Gaya belajar Auditori (Auditory Learners) mengandalkan pada pendengaran untuk bisa memahami dan mengingatnya. Karakteristik model belajar seperti ini benar-benar menempatkan pendengaran sebagai alat utama menyerap informasi atau pengetahuan. Karakter pertama orang yang memiliki gaya belajar ini adalah semua informasi hanya bisa diserap melalui pendengaran, kedua memiliki kesulitan untuk menyerap informasi dalam bentuk tulisan secara langsung, ketiga memiliki kesulitan menulis ataupun membaca

c. Gaya belajar Kinestetik (Kinesthetic Learners) mengharuskan individu yang bersangkutan menyentuh sesuatu yang memberikan informasi tertentu agar ia bisa mengingatnya. Karakter pertama adalah menempatkan tangan sebagai alat penerima informasi utama agar bisa terus mengingatnya. Hanya dengan memegangnya saja, seseorang yang memiliki gaya ini bisa menyerap informasi tanpa harus membaca penjelasannya. ${ }^{2}$

Hasil belajar sering dicerminkan sebagai nilai yang menentukan berhasil tidaknya siswa setelah belajar.Perubahan perilaku disebabkan karena siswa mencapai penugasan atas sejumlah bahan diberikan dalam proses belajar mengaja biasa disebut sebagai hasil belajar. Adapun definisi hasil belajar menurut para ahli sebagai berikut :

1) Menurut RifaI dan Anni, hasil belajar merupakan perubahan perilaku yang diperoleh peserta didik setelah mengalami kegiatan belajar. Perolehan aspek-aspek perubahan perilaku tersebut tergantung pada apa yang di pelajari oleh peserta didik.

${ }^{1}$ Bobby DePorter dan Mike Hernacki, terjemah Abdurrahman Alwiyah, , Quantum Learning Membiasakan Belajar Nyaman dan Menyenangkan, (Bandung: Kaifa PT Mizan Pustaka, 2005) h. 56

${ }^{2}$ Nini Subini, Mengatasi Kesulitan Belajar pada Anak, (Yogyakarta: Javalitera, 2012), h. 118. 
2) Menurut Sanjaya, hasil belajar berkaitan dengan pencapaian dalam memperoleh kemampuan sesuai dengan tujuan khusus yang direncanakan.

3) Menurut Suprijono, hasil belajar adalah pola-pola perbuatan, pengertian-pengertian, sikap-sikap, apresiasi dan keterampilan. ${ }^{3}$

Berdasarkan uraian di atas dapat dikemukakan bahwa hasil belajar merupakan perubahan prilaku yang diperoleh pembelajaran setelah menjalani proses belajar sehingga perubahan dari hasil masukan pribadi berupa motivasi dan harapan untuk berhasil dan masukan dari lingkungan berupa rancangan dan pengelolaan motivasional. Adapun hasil belajar dapat berupa :

1) Informasi verbal, untuk mengungkapkan pengetahuan dalam bentuk bahasa, baik lisan maupun tulisan. Kemampuan merespon secara spesifik terhadap rangsangan spesifik. Kemampuan tersebut tidak memerlukan manipulasi symbol, pemecahan masalah maupun penerapan aturan.

2) Keterampilan intelektual, yaitu kemampuan mempresentasikan konsep dan lambing. Keterampilan intelektual meliputi kemampuan mengkategorikan, analitis-sitesis fakta konsep dan mengembangkan prinsipprinsip keilmuan.

3) Strategi kognitif, yaitu kecakapan menyalurkan dan mengarahkan aktivitas kognitifnya sendiri. Kemampuan ini meliputi penggunaan konsep dan kaidah dalam memecahkan masalah.

4) Keterampilan motorik, yaitu kemampuan melakukan serangkaian gerak jasmani dalam urusan dan koordinasi sehingga terwujud otomatisme gerak jasmani.

5) Sikap, yaitu kemampuan menerima dan menolak objek berdasarkan penilaian terhadap objek tersebut. Sikap meliputi kemampuan menginternalisasi dan eksternalisasi nilai-nilai. Sikap merupakan kemampuan menjadikan nilai sebagai standar perilaku. ${ }^{4}$

Berdasarkan pengamatan penulis, terdapat siswa yang mengalami kesulitan dalam mengikuti pelajaran yang pada akhirnya berdampak pada hasil belajarnya. Siswa juga kerap kesulitan menyesuaikan cara belajar mereka dengan cara mengajar guru di sekolah. Terdapat siswa yang lebih suka ketika guru mereka mengajar dengan cara menuliskan segalanya di papan tulis yang artinya siswa dalam kondisi ini memiliki gaya belajar visual.

\footnotetext{
${ }^{3}$ Asep Jihad, Abdul Haris, Evaluasi Pembelajaran, (Yogyakarta: Multi Pressindo, 2010), h. 59 .

${ }^{4}$ Samsul Nizar, Pengantar Dasar-dasar Pemikiran Pendidikan Islam (Jakarta : Gaya Media Pratama, 2001) h. 80.
} 
Selain itu, terdapat siswa yang lebih senagng belajar ketika guru mengajar dengan cara menyampaikannya secara lisan dan siswa mendengarkan untuk bisa memahaminya yang artinya siswa dalam kondisi ini memiliki gaya belajar auditori. Sementara itu, ada siswa yang lebih suka diberikan contoh melalui media pembelajaran yang dapat disentuh kemudian menginterpretasikanny sebgai informsi ilmu pengetahuan yang artinya siswa dalam kondisi ini memiliki gaya belajar kinestetik.

Berdasarkan uraian tersebut, dapat dikemukakan bahwa kemampuan siswa untuk memahami dan menyerap pelajaran sudah pasti berbeda tingkatannya. Hal ini juga terjadi pada siswa SMA Negeri 4 Palopo yang merupakan salah satu lembaga pendidikan yang bertujuan memerhatikan sekaligus menciptakan kegiatan belajar mengajar yang kondusif dan menyenangkan.Akan tetapi,dalam pelaksanaan pembelajaran hasil belajar siswa bervariatif. Hal ini disebabkan gaya belajar siswa yang berbeda-beda terdapat siswa yang cepat, sedang dan ada pula yang sangat lambat dalam memahami konsep materi yang diberikan oleh guru. Karenanya, siswa seringkali harus menempuh cara berbeda untuk bisa memahami sebuah informasi atau pelajaran yang sama.

Penelitian ini bertujuan untuk mengkaji lebih dalam tentang pengaruh gaya belajar siswa terhadap hasil belajar siswa di kelas X SMA Negeri 4 Palopo.

\section{Metode Penelitian}

Penelitian ini menggunakan jenis penelitian kuantitatif dengan desain penelitian ex-post facto yang menggunakan alat bantu ilmu statistik bersifat inferensial dan deskriptif yang menjadi populasi untuk diteliti adalah seluruh siswa kelas $\mathrm{X}_{7}$ dengan $\mathrm{X}_{8}$ tahun pelajaran 2016-2017 berjumlah 51 orang. Jadi, jumlah subjek dalam populasi penelitian ini adalah 51 orang dengan Teknik sampling jenuh teknik pengumpulan data yang akan digunakan dalam penilitian ini adalah teknik angket dan dokumentasi yang selanjutnya dianalisis dengan menggunakan statistik deskriptif dan statistik inferensial. 


\section{Hasil Penelitian}

Berdasakan hasil penelitian diperoleh sebagai berikut:

Tabel 1. Deskripsi Hasil penelitian

\begin{tabular}{|c|c|c|c|c|}
\hline \multirow{2}{*}{ Statistik } & \multicolumn{3}{|c|}{ Gaya belajar } & \multirow{2}{*}{$\begin{array}{c}\text { Hasil } \\
\text { Belajar }\end{array}$} \\
\hline & Visual & Auditori & Kinestetik & \\
\hline Ukuran Sampel & 51 & 51 & 51 & 51 \\
\hline Rata-rata & 70.8039 & 69.4118 & 72.5882 & 78.059 \\
\hline $\begin{array}{l}\text { Standar } \\
\text { Deviasi }\end{array}$ & 7.60268 & 8.71361 & 8.71361 & 14.42 \\
\hline Varians & 57.801 & 75.927 & 107.607 & 207.94 \\
\hline Rentang Skor & 31 & 31 & 34 & 46 \\
\hline Nilai Terendah & 52 & 52 & 56 & 50 \\
\hline Nilai Tertinggi & 83 & 83 & 90 & 96 \\
\hline
\end{tabular}

Sumber: Hasil analisis data angket penelitian yang diolah, Tahun 2017

1. Hasil Analisis Statistik Inferensial

a. Uji Asumsi

1) Uji normalitas data

Tabel 2. Uji Normalitas Data Tests of Normality

\begin{tabular}{|c|c|c|c|c|c|c|}
\hline & \multicolumn{3}{|c|}{ Kolmogorov-Smirnova } & \multicolumn{3}{|c|}{ Shapiro-Wilk } \\
\hline & Statistic & $\mathrm{df}$ & Sig. & Statistic & $\mathrm{df}$ & Sig. \\
\hline Gaya belajar visual & .165 & 51 & .010 & .921 & 51 & .011 \\
\hline $\begin{array}{l}\text { Gaya belajar } \\
\text { auditori }\end{array}$ & .151 & 51 & .008 & .932 & 51 & .009 \\
\hline $\begin{array}{l}\text { Gaya belajar } \\
\text { kinestetik }\end{array}$ & .129 & 51 & .033 & .926 & 51 & .034 \\
\hline
\end{tabular}

a. Lilliefors Significance Correction

Dengan demikian, signifikansi untuk seluruh variabel lebih besar dari 0,05 sehingga dapat disimpulkan bahwa data pada variabel gaya belajar visual, auditori, dan kinestetik siswa berdistribusi normal. Berikut ini adalah diagram yang mendukung kesimpulan bahwa data dalam penelitian ini berdistribusi normal: 

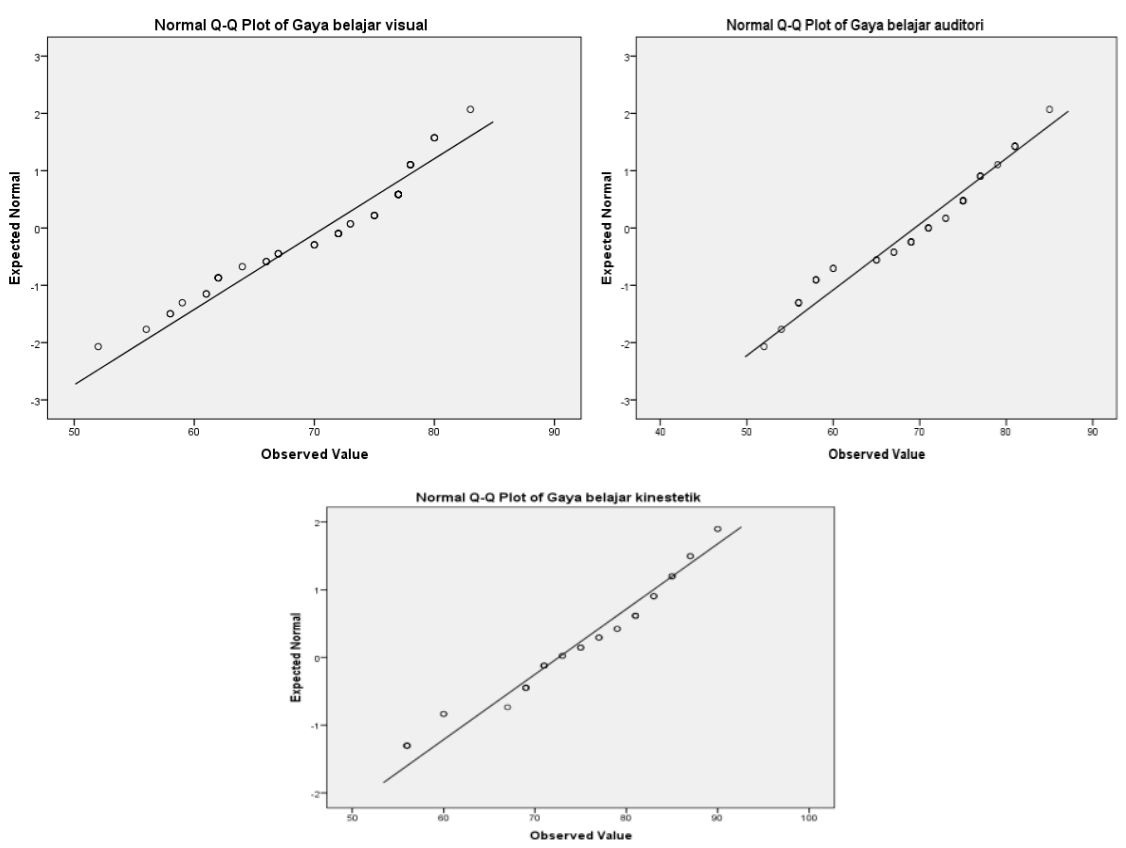

Pada diagram di atas, dapat dilihat plot-plot pada tiap variabel mengikuti garis fit line, maka variabel berdistribusi normal.

2) Uji homogenitas varians

Uji homogenitas varians dapat di uji melalui program SPSS (Statistical Product and Service Solution) Ver. 22 for windows diuraikan pada tabel berikut:

Tabel 4.6 Uji Homogenitas Varians

Test of Homogeneity of Variances

\begin{tabular}{|l|r|r|r|r|}
\hline & $\begin{array}{c}\text { Levene } \\
\text { Statistic }\end{array}$ & \multicolumn{1}{c|}{ df1 } & \multicolumn{1}{c|}{ df2 } & \multicolumn{1}{c|}{ Sig. } \\
\hline Gaya belajar visual & 1.724 & 10 & 32 & .118 \\
Gaya belajar auditori & 1.464 & 10 & 32 & .198 \\
Gaya belajar kinestetik & 1.258 & 10 & 32 & .294 \\
\hline
\end{tabular}

Berdasarkan analisis data uji homogenitas varians diperoleh taraf signifikansi gaya belajar visual sebesar 0,118 , taraf signifikansi gaya belajar auditori sebesar 0,198 dan taraf signifikansi gaya belajar kinestetik sebesar 0,294 . Dengan demikian, taraf signifikansi $(0,118>0,05),(0,198>0,05)$ dan $(0,294>0,05)$ maka $H_{0}$ diterima sehingga sampel dinyatakan berasal dari varians yang homogen.

\section{b. Pengujian Hipotesis}

1) Pengujian hipotesis pengaruh gaya belajar visual siswa terhadap hasil belajar pendidikan agama Islam di kelas X SMA Negeri 4 Palopo. 
Tabel 4. 7 Analisis pengaruh gaya belajar visual siswa terhadap hasil belajar pendidikan agama Islam di kelas X SMA Negeri 4 Palopo Coefficients $^{\mathrm{a}}$

\begin{tabular}{|c|r|r|r|r|r|}
\hline Model & \multicolumn{2}{|c|}{$\begin{array}{c}\text { Unstandardized } \\
\text { Coefficients }\end{array}$} & $\begin{array}{c}\text { Standardize } \\
\mathrm{d} \\
\text { Coefficients }\end{array}$ & $\mathrm{t}$ & Sig. \\
\cline { 2 - 5 } & \multicolumn{1}{|c|}{ B } & Std. Error & \multicolumn{1}{c|}{ Beta } & & \\
\hline \multirow{2}{*}{$\begin{array}{l}\text { (Constant) } \\
\text { Gaya belajar } \\
\text { visual }\end{array}$} & 102.201 & 18.979 & & 5.385 & .000 \\
\hline
\end{tabular}

a. Dependent Variable: Hasil belajar PAI

Berdasarkan tabel analisis regresi sederhana terhadap data skor hasil belajar pendidikan agama Islam (Y) dan gaya belajar visual siswa (X1) menghasilkan konstanta" $\alpha$ " sebesar 102.201 dan koefisien regresi " $\beta X_{1}$ " sebesar 0,341 sehingga persamaan regresinya yaitu: $\mathrm{Y}=\alpha+\beta \mathrm{X}_{1}$ atau $\overline{\mathrm{y}}=$ $102.201+0,341$. Pengujian keberartian antara hasil belajar pendidikan agama Islam (Y) dan gaya belajar visual siswa (X1) dapat dikemukakan melalui persamaan regresi $\overline{\mathrm{Y}}=102.201+0,341$ menunjukkan kenaikan setiap satu skor pada gaya belajar visual siswa (X1) menyebabkan kenaikan sebesar 0,341 pada skor hasil belajar pendidikan agama Islam (Y) pada konstanta sebesar $102.201+0,341$.

Pengujian signifikansi koefisien regresi sederhana dilakukan dengan tujuan untuk mengetahui pengaruh yang terjadi sehingga dapat digeneralisasikan atau berlaku untuk populasi. Adapun langkah pengujianya, yaitu dengan menentukan hipotesis. Adapun hipotesis dalam penelitian ini sebagai berikut :

$\mathrm{H}_{0}=$ Tidak ada pengaruh gaya belajar visual siswa terhadap hasil belajar pendidikan agama Islam di kelas X SMA Negeri 4 Palopo

$\mathrm{H}_{\mathrm{a}}=$ Ada pengaruh gaya belajar visual siswa terhadap hasil belajar pendidikan agama Islam di kelas X SMA Negeri 4 Palopo.

Pengujian tingkat signifikasi $a=5 \%$, yang berarti bahwa untuk mengambil keputusan untuk menolak hipotesa yang benar sebesar $5 \%$ atau 0,05. Adapun hasil analisis melalui tabel model summary menunjukkan koefisien perolehan nilai determinan sebagai berikut: 
Tabel 4.8 Koefisien perolehan nilai determinan

Gaya belajar visual siswa terhadap hasil belajar pendidikan agama Islam

Model Summaryb

\begin{tabular}{|c|c|c|c|c|c|c|c|c|c|}
\hline \multirow[t]{2}{*}{ Model } & \multirow[t]{2}{*}{$\mathrm{R}$} & \multirow{2}{*}{$\begin{array}{c}\mathrm{R} \\
\text { Squar } \\
\mathrm{e}\end{array}$} & \multirow{2}{*}{$\begin{array}{c}\text { Adjuste } \\
\text { d R } \\
\text { Square }\end{array}$} & \multirow{2}{*}{$\begin{array}{c}\text { Std. } \\
\text { Error of } \\
\text { the } \\
\text { Estimate }\end{array}$} & \multicolumn{5}{|c|}{ Change Statistics } \\
\hline & & & & & $\begin{array}{c}\text { R } \\
\text { Square } \\
\text { Change }\end{array}$ & $\begin{array}{c}\mathrm{F} \\
\text { Change }\end{array}$ & $\mathrm{df1}$ & $\mathrm{df} 2$ & $\begin{array}{c}\text { Sig. F } \\
\text { Chang } \\
\text { e }\end{array}$ \\
\hline 1 & $.180^{\mathrm{a}}$ & .132 & .013 & $\begin{array}{r}14.3291 \\
0\end{array}$ & .032 & 1.636 & 1 & 49 & .207 \\
\hline
\end{tabular}

a. Predictors: (Constant), Gaya belajar visual

b. Dependent Variable: Hasil belajar PAI

Berdasarkan tabel tersebut, analisis regresi sederhana terhadap aspek gaya belajar visual siswa (X1) terhadap hasil belajar pendidikan agama Islam (Y) menunjukkan koefisien korelasi $r_{\mathrm{y}}$ sebesar 0,180. Hasil pengujian keberartian koefisien regresi dengan menggunakan uji t diperoleh bahwa $t_{\text {hitung }}=5.385$ signifikan pada taraf nyata 0,207. Adapun tabel pada taraf signifikansi 0,05 dengan $n=51$ maka $\mathrm{df}=\mathrm{n}-2$ yaitu $51-2=49$. Jadi, nilai tabel $=1,677.5$ Dengan demikian dapat dikemukakan bahwa thitung $5.385 \geq t_{\text {tabel }}$ 1,677 dengan $\alpha=0,05$ sehingga $\mathrm{H}_{0}$ ditolak dan Ha diterima. Hal ini berarti bahwa ada pengaruh aspek gaya belajar visual siswa (X1) terhadap hasil belajar pendidikan agama Islam (Y)

Pengaruh antara gaya belajar visual siswa (X1) terhadap hasil belajar pendidikan agama Islam (Y) didukung oleh koefisien $\mathrm{R}^{2}$ (R Square) sebesar 0,132 yang menunjukkan bahwa terdapat pengaruh signifikan antara aspek gaya belajar visual siswa (X1) terhadap hasil belajar pendidikan agama Islam (Y) didukung oleh koefisien determinasi sebesar 13,2\%. Hal ini berarti bahwa 13,2\% gaya belajar visual siswa (X 1) terhadap hasil belajar pendidikan agama Islam (Y) yang dijelaskan oleh variasi aspek melalui persamaan regresi $\mathrm{Y}=102.201+0,341$.

2) Pengujian hipotesis pengaruh gaya belajar auditori siswa terhadap hasil belajar pendidikan agama Islam di kelas X SMA Negeri 4 Palopo.

${ }^{5}$ Wiratna Sujarweni, SPSS Untuk Penelitian, 'Tabel distribusi T', (Yogyakarta: Pustaka Baru Press, 2015), h. 244. 
Tabel 4. 9 Analisis pengaruh gaya belajar auditori siswa terhadap hasil belajar pendidikan agama Islam di kelas X SMA Negeri 4 Palopo Coefficients ${ }^{a}$

\begin{tabular}{|r|r|r|r|r|r|}
\hline \multicolumn{1}{|c|}{ Model } & \multicolumn{2}{|c|}{$\begin{array}{c}\text { Unstandardized } \\
\text { Coefficients }\end{array}$} & $\begin{array}{r}\text { Standardize } \\
\mathrm{d} \\
\text { Coefficients }\end{array}$ & $\mathrm{t}$ & Sig. \\
\cline { 2 - 6 } & \multicolumn{2}{|c|}{$\mathrm{B}$} & Std. Error & \multicolumn{1}{c|}{ Beta } & \\
\hline \multirow{2}{*}{$\begin{array}{l}\text { (Constant) } \\
\begin{array}{l}\text { Gaya belajar } \\
\text { auditori }\end{array}\end{array}$} & 95.652 & 16.341 & & 5.854 & .000 \\
\hline
\end{tabular}

a. Dependent Variable: Hasil belajar PAI

Berdasarkan tabel analisis regresi sederhana terhadap data skor hasil belajar pendidikan agama Islam (Y) dan gaya belajar auditori siswa (X2) menghasilkan konstanta" $\alpha$ " sebesar 95.652 dan koefisien regresi " $\beta \mathrm{X}_{2}$ " sebesar 0,253 sehingga persamaan regresinya yaitu: $\mathrm{Y}=\alpha+\beta \mathrm{X}_{1}$ atau $\overline{\mathrm{y}}=$ $95.652+0,253$. Pengujian keberartian antara hasil belajar pendidikan agama Islam (Y) dan gaya belajar auditori siswa (X2) dapat dikemukakan melalui persamaan regresi $\overline{\mathrm{y}}=95.652+0,253$ menunjukkan kenaikan setiap satu skor pada belajar auditori siswa (X2) menyebabkan kenaikan sebesar 0,341 pada skor hasil belajar pendidikan agama Islam (Y) pada konstanta sebesar $95.652+0,253$.

Pengujian signifikansi koefisien regresi sederhana dilakukan dengan tujuan untuk mengetahui pengaruh yang terjadi sehingga dapat digeneralisasikan atau berlaku untuk populasi. Adapun langkah pengujianya, yaitu dengan menentukan hipotesis. Adapun hipotesis dalam penelitian ini sebagai berikut :

$\mathrm{H}_{0}=$ Tidak ada pengaruh gaya belajar auditori siswa terhadap hasil belajar pendidikan agama Islam di kelas X SMA Negeri 4 Palopo

$\mathrm{H}_{\mathrm{a}}=$ Ada pengaruh gaya belajar auditori siswa terhadap hasil belajar pendidikan agama Islam di kelas X SMA Negeri 4 Palopo.

Pengujian tingkat signifikasi $a=5 \%$, yang berarti bahwa untuk mengambil keputusan untuk menolak hipotesa yang benar sebesar 5\% atau 0,05 . Adapun hasil analisis melalui tabel model summary menunjukkan koefisien perolehan nilai determinan sebagai berikut 
Tabel 4.10 Koefisien perolehan nilai determinan Gaya belajar auditori siswa terhadap hasil belajar pendidikan agama Islam

Model Summaryb

\begin{tabular}{|c|c|c|c|c|c|c|c|c|c|}
\hline \multirow[t]{2}{*}{ Model } & \multirow[t]{2}{*}{$\mathrm{R}$} & \multirow{2}{*}{$\begin{array}{c}\mathrm{R} \\
\text { Squar } \\
\mathrm{e}\end{array}$} & \multirow{2}{*}{$\begin{array}{l}\text { Adjusted } \\
\text { R Square }\end{array}$} & \multirow{2}{*}{$\begin{array}{c}\text { Std. } \\
\text { Error of } \\
\text { the } \\
\text { Estimate }\end{array}$} & \multicolumn{5}{|c|}{ Change Statistics } \\
\hline & & & & & $\begin{array}{c}\text { R } \\
\text { Square } \\
\text { Change }\end{array}$ & $\begin{array}{c}\mathrm{F} \\
\text { Change }\end{array}$ & df1 & $\mathrm{df} 2$ & $\begin{array}{c}\text { Sig. F } \\
\text { Chang } \\
\text { e }\end{array}$ \\
\hline 1 & $\begin{array}{r}.153 \\
\text { a }\end{array}$ & .123 & .004 & $\begin{array}{r}14.3945 \\
4\end{array}$ & .023 & 1.177 & 1 & 49 & .283 \\
\hline
\end{tabular}

a. Predictors: (Constant), Gaya belajar auditori

b. Dependent Variable: Hasil belajar PAI

Berdasarkan tabel tersebut, analisis regresi sederhana terhadap aspek gaya belajar auditori siswa (X2 ) terhadap hasil belajar pendidikan agama Islam (Y) menunjukkan koefisien korelasi $r_{\mathrm{y}}$ sebesar 0,153 . Hasil pengujian keberartian koefisien regresi dengan menggunakan uji t diperoleh bahwa thitung $=5.854$ signifikan pada taraf nyata 0,000 . Adapun tabel pada taraf signifikansi 0,05 dengan $n=51$ maka $\mathrm{df}=\mathrm{n}-2$ yaitu $51-2=49$. Jadi, nilai tabel $=1,677 .{ }^{6}$ Dengan demikian dapat dikemukakan bahwa thitung $5.854 \geq$ t tabel 1,677 dengan $\alpha=0,05$ sehingga $\mathrm{H}_{0}$ ditolak dan Ha diterima. Hal ini berarti bahwa ada pengaruh aspek gaya belajar auditori siswa (X2) terhadap hasil belajar pendidikan agama Islam $(\mathrm{Y})$

Pengaruh antara gaya belajar auditori siswa (X2) terhadap hasil belajar pendidikan agama Islam (Y) didukung oleh koefisien $\mathrm{R}^{2}$ (R Square) sebesar 0,123 yang menunjukkan bahwa terdapat pengaruh signifikan antara aspek gaya belajar auditori siswa (X2) terhadap hasil belajar pendidikan agama Islam (Y) didukung oleh koefisien determinasi sebesar 12,3\%. Hal ini berarti bahwa 12,3\% gaya belajar auditori siswa (X2) terhadap hasil belajar pendidikan agama Islam (Y) yang dijelaskan oleh variasi aspek melalui persamaan regresi $\mathrm{Y}=95.652+0,253$.

2. Pengujian hipotesis pengaruh gaya belajar kinestetik siswa terhadap hasil belajar pendidikan agama Islam di kelas X SMA Negeri 4 Palopo

Hasil analisis pengujian hipotesis dilakukan dengan mencari pengaruh gaya belajar kinestetik siswa (X3) terhadap hasil belajar pendidikan agama Islam (Y) di kelas X SMA Negeri 4 Palopo. Hal ini dilakukan dengan menggunakan pengolahan data melalui program SPSS (Statistical Product and Service Solution) Ver. 22 for windows sebagai berikut:

${ }^{6}$ Wiratna Sujarweni, SPSS Untuk Penelitian, 'Tabel distribusi T', h. 244. 
Tabel 4. 11 Analisis pengaruh gaya belajar kinestetik siswa terhadap hasil belajar pendidikan agama Islam di kelas X SMA Negeri 4 Palopo

Coefficientsa

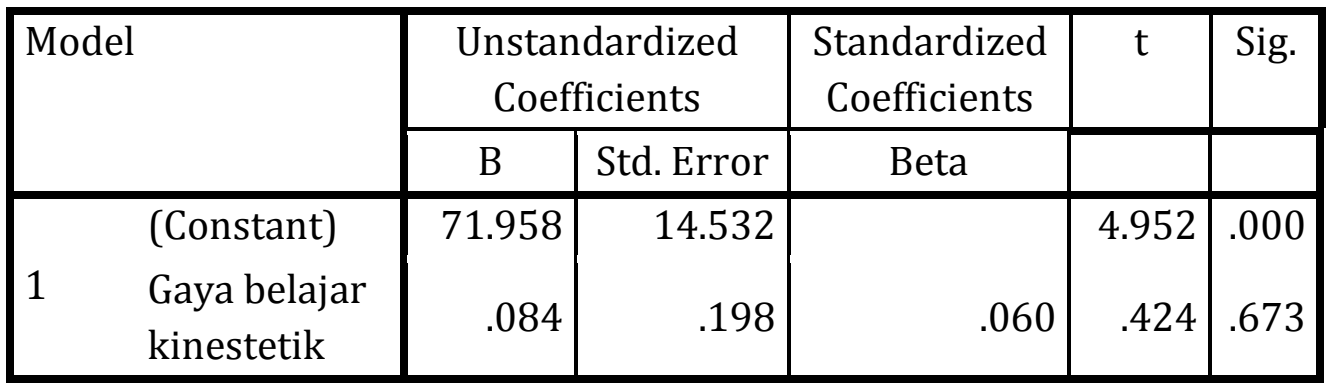

a. Dependent Variable: Hasil belajar PAI

Berdasarkan tabel analisis regresi sederhana terhadap data skor hasil belajar pendidikan agama Islam (Y) dan gaya belajar kinestetik siswa (X3) menghasilkan konstanta" $\alpha$ " sebesar 71.958 dan koefisien regresi " $\mathrm{Bx} 3$ " sebesar 0,084 sehingga persamaan regresinya yaitu: $\mathrm{Y}=\alpha+\beta \mathrm{X}_{1}$ atau $\overline{\mathrm{y}}=$ $71.958+0,084$. Pengujian keberartian antara hasil belajar pendidikan agama Islam (Y) dan gaya belajar kinestetik siswa (X3) dapat dikemukakan melalui persamaan regresi $\bar{y}=71.958+0,084$ menunjukkan kenaikan setiap satu skor pada gaya belajar kinestetik siswa (X3) menyebabkan kenaikan sebesar 0,084 pada skor hasil belajar pendidikan agama Islam (Y) pada konstanta sebesar $71.958+0,084$.

Pengujian signifikansi koefisien regresi sederhana dilakukan dengan tujuan untuk mengetahui pengaruh yang terjadi sehingga dapat digeneralisasikan atau berlaku untuk populasi. Adapun langkah pengujianya, yaitu dengan menentukan hipotesis. Adapun hipotesis dalam penelitian ini sebagai berikut :

$\mathrm{H}_{0}=$ Tidak ada pengaruh gaya belajar kinestetik siswa terhadap hasil belajar pendidikan agama Islam di kelas X SMA Negeri 4 Palopo

$\mathrm{H}_{\mathrm{a}}=$ Ada pengaruh gaya belajar kinestetik siswa terhadap hasil belajar pendidikan agama Islam di kelas X SMA Negeri 4 Palopo.

Pengujian tingkat signifikasi $a=5 \%$, yang berarti bahwa untuk mengambil keputusan untuk menolak hipotesa yang benar sebesar 5\% atau 0,05 . Adapun hasil analisis melalui tabel model summary menunjukkan koefisien perolehan nilai determinan sebagai berikut 
Tabel 4.12 Koefisien perolehan nilai determinan Gaya belajar kinestetik siswa terhadap hasil belajar pendidikan agama Islam

\section{Model Summaryb}

\begin{tabular}{|l|c|c|c|c|c|c|c|c|c|}
\hline Model & $\mathrm{R}$ & $\mathrm{R}$ & Adjuste & Std. Error & \multicolumn{4}{|c|}{ Change Statistics } \\
\cline { 6 - 10 } & & $\begin{array}{c}\text { Squar } \\
\mathrm{e}\end{array}$ & $\begin{array}{c}\text { d R } \\
\text { Square }\end{array}$ & $\begin{array}{c}\text { of the } \\
\text { Estimate }\end{array}$ & $\begin{array}{c}\mathrm{R} \\
\text { Square } \\
\text { Change }\end{array}$ & $\begin{array}{c}\mathrm{F} \\
\text { Chang } \\
\mathrm{e}\end{array}$ & $\mathrm{df1}$ & $\begin{array}{c}\mathrm{df} \\
2\end{array}$ & $\begin{array}{c}\text { Sig. F } \\
\text { Chang } \\
\mathrm{e}\end{array}$ \\
\hline 1 & $.060^{\mathrm{a}}$ & .105 & -.017 & 14.53975 & .004 & .180 & 1 & 49 & .673 \\
\hline
\end{tabular}

a. Predictors: (Constant), Gaya belajar kinestetik

b. Dependent Variable: Hasil belajar PAI

Berdasarkan tabel tersebut, analisis regresi sederhana terhadap aspek gaya belajar kinestetik siswa (X3) terhadap hasil belajar pendidikan agama Islam (Y) menunjukkan koefisien korelasi $r_{\mathrm{y}}$ sebesar 0,060 . Hasil pengujian keberartian koefisien regresi dengan menggunakan uji $t$ diperoleh bahwa $t_{\text {hitung }}=4.952$ signifikan pada taraf nyata 0,000 . Adapun $t_{\text {tabel }}$ pada taraf signifikansi 0,05 dengan $n=51$ maka $\mathrm{df}=\mathrm{n}-2$ yaitu $51-2=49$. Jadi, nilai tabel $=1,677.7$ Dengan demikian dapat dikemukakan bahwa thitung $4.952 \geq$ tabel 1,677 dengan $\alpha=0,05$ sehingga $\mathrm{H}_{0}$ ditolak dan Ha diterima. Hal ini berarti bahwa ada pengaruh aspek gaya belajar kinestetik siswa (X3) terhadap hasil belajar pendidikan agama Islam (Y)

Pengaruh antara gaya belajar kinestetik siswa (X3) terhadap hasil belajar pendidikan agama Islam (Y) didukung oleh koefisien $\mathrm{R}^{2}$ (R Square) sebesar 0,105 yang menunjukkan bahwa terdapat pengaruh signifikan antara aspek gaya belajar kinestetik siswa (X3) terhadap hasil belajar pendidikan agama Islam (Y) didukung oleh koefisien determinasi sebesar 10,5\%. Hal ini berarti bahwa 10,5\% gaya belajar kinestetik siswa (X3) terhadap hasil belajar pendidikan agama Islam (Y) yang dijelaskan oleh variasi aspek melalui persamaan regresi $Y=71.958+0,084$.

\section{Pembahasan}

Kemampuan seseorang untuk memahami dan menyerap pelajaran berbeda tingkatnya. Ada yang cepat, sedang, dan ada pula yang sangat lambat. Oleh karena itu, mereka seringkali harus menempuh cara berbeda untuk bisa memahami sebuah informasi atau pelajaran yang sama. Gaya belajar merupakan cara belajar yang khas bagi siswa. Apapun cara yang dipilih, perbedaan gaya belajar itu menunjukkan cara tercepat dan terbaik bagi setiap individu untuk bisa menyerap sebuah informasi dari luar dirinya. Jadi, gaya

\footnotetext{
${ }^{7}$ Wiratna Sujarweni, SPSS Untuk Penelitian, 'Tabel distribusi T', h. 244.
} 
belajar ialah cara siswa bereaksi dan menggunakan perangsang-perangsang yang diterimanya dalam proses belajar. Salah satu gaya belajar siswa yang secara umum digunakan yaitu gaya belajar visual siswa.

Gaya belajar visual menitikberatkan pada ketajaman penglihatan. Artinya, bukti-bukti konkret harus diperlihatkan terlebih dahulu agar siswa paham. Gaya belajar seperti ini mengandalkan penglihatan atau melihat dulu buktinya untuk kemudian bisa mempercayainya. Karakteristik siswa yang memiliki gaya belajar visual diantaranya kebutuhan melihat sesuatu (informasi/pelajaran) secara visual untuk mengetahuinya atau memahaminya. Selain itu, biasanya tingkat kepekaan kuat terhadap warna dan sulit mengikuti anjuran secara lisan sehingga seringkali salah menginterpretasikan kata atau ucapan.

Analisis regresi sederhana gaya belajar visual siswa terhadap hasil belajar pendidikan agama Islam memiliki pengaruh berdasarkan koefisien $\mathrm{R}^{2}$ (R Square) sebesar 0,132 atau 13,2 \% yang menunjukkan bahwa pengaruh signifikan antara aspek gaya belajar visual siswa dan hasil belajar pendidikan agama Islam dapat digunakan karena memiliki pengaruh terutama pada hasil belajar siswa. Berikut ini adalah tabel hasil angket gaya belajar visual siswa untuk dijadikan acuan dalam mengklasifikasi tingkat persentase yang diperoleh siswa yang belajar dengan gaya visual di kelas $\mathrm{X}\left(\mathrm{X}_{7} \& \mathrm{X}_{8}\right)$ SMA Negeri 4 Palopo.

Jika skor gaya belajar visual siswa dikelompokkan kedalam empat kategori maka diperoleh tabel distribusi frekuensi dan persentase gaya belajar visual siswa. Distribusi frekuensi berfungsi untuk menunjukkan jumlah atau banyaknya item dalam setiap kategori atau kelas. ${ }^{8}$ Jadi, skor gaya belajar visual siswa dikelompokkan berdasarkan banyaknya item dari setiap kategori sehingga hasil pengukurannya dianalisis melalui metode statistik yang kemudian diberikan interpretasi secara kualitatif. ${ }^{9}$ Adapun tabel distribusi frekuensi dan persentase gaya belajar visual siswa adalah sebagai berikut:

Tabel 4.14 Perolehan Persentase Kategorisasi Gaya Belajar Visual

Siswa

\begin{tabular}{|c|l|c|c|}
\hline \multicolumn{1}{|c|}{ Skor } & \multicolumn{1}{|c|}{ Kategori } & Frekuensi & Persentase (\%) \\
\hline $51-60$ & Kurang Baik & 5 & $10 \%$ \\
$61-70$ & Cukup Baik & 16 & $31 \%$ \\
$71-80$ & Baik & 29 & $57 \%$ \\
$81-90$ & Sangat Baik & 1 & $2 \%$ \\
\hline \multicolumn{2}{|r|}{ Jumlah } & 51 & $100 \%$ \\
\hline
\end{tabular}

${ }^{8}$ J. Supranto, Statistik Teori dan Aplikasi, (Cet I; Jakarta : Erlangga , 2000 ) h. 63

${ }^{9}$ Anas Sudijono, Pengatar Evaluasi Pendidikan (Jakarta: Raja Grafindo Persada, 2006) h. 35 . 


\section{Sumber: Hasil analisis data angket penelitian yang diolah, Tahun 2017}

\section{Gaya belajar auditori siswa}

Gaya belajar yang dimiliki siswa banyak sekali macamnya dan unik bila dilihat. Upaya yang dilakukan untuk mengenali dan mengkategorikan cara manusia belajar, cara memasukkan informasi ke dalam otak. Secara garis besar, dapat dilakukan berdasarkan pada pemprosesan informasi atau menentukan cara yang berbeda dalam memandang dan memproses informasi yang baru dengan berpatokan pada tingkat ketergantungan terhadap indera tertentu. Salah satu gaya belajar dengan menjadikan alat indera sebagai cara untuk memahami informasi yaitu gaya belajar auditori siswa yang mengandalkan pendengaran untuk bisa memahami dan mengingat informasi yang diberikan.

Karakteristik model belajar seperti ini benar-benar menempatkan pendengaran sebagai alat utama menyerap informasi atau pengetahuan. Artinya,seorang harus mendengar, baru kemudian bisa mengingat dan memahami informasi itu. Karakter orang yang memiliki gaya belajar ini adalah semua informasi hanya bisa diserap melalui pendengaran sehingga memiliki kesulitan untuk menyerap informasi dalam bentuk tulisan secara langsung. Berikut ini adalah tabel hasil angket gaya belajar auditori siswa untuk dijadikan acuan dalam mengklasifikasi tingkat persentase yang diperoleh siswa yang belajar dengan gaya visual di kelas $\mathrm{X}_{\left(\mathrm{X}_{7} \& \mathrm{X}_{8}\right)}$ SMA Negeri 4 Palopo.

Pendekatan dalam mengklasifikasikan atau membedakan gaya belajar disebabkan karena setiap pendekatan yang digunakan mengakses aspek yang berbeda secara kognitif. Analisis regresi sederhana gaya belajar auditori siswa terhadap hasil belajar pendidikan agama Islam memiliki pengaruh berdasarkan koefisien $\mathrm{R}^{2}$ (R Square) sebesar 0,123 atau 12,3\% yang menunjukkan bahwa pengaruh signifikan antara aspek gaya belajar auditori siswa dan hasil belajar pendidikan agama Islam dapat digunakan karena memiliki pengaruh terutama pada hasil belajar siswa. Adapun skor gaya belajar auditori siswa jika dikelompokkan kedalam empat kategori maka diperoleh tabel distribusi frekuensi dan persentase gaya belajar auditori siswa sebagai berikut: 
Tabel 16. Perolehan Persentase Kategorisasi Gaya Belajar Auditori Siswa

\begin{tabular}{|l|l|c|c|}
\hline \multicolumn{1}{|c|}{ Skor } & \multicolumn{1}{|c|}{ Kategori } & Frekuensi & Persentase (\%) \\
\hline $51-60$ & Kurang Baik & 13 & $25 \%$ \\
$61-70$ & Cukup Baik & 10 & $20 \%$ \\
$71-80$ & Baik & 22 & $43 \%$ \\
$81-90$ & Sangat Baik & 6 & $12 \%$ \\
\hline \multicolumn{2}{|r|}{ Jumlah } & 51 & $100 \%$ \\
\hline
\end{tabular}

Sumber: Hasil analisis data angket penelitian yang diolah, Tahun 2017

2. Gaya belajar kinestetik siswa

Gaya belajar dengan gaya pengajaran yang distrukturkan bagi siswa berpengaruh secara signifikan terhadap hasil belajar sehingga gaya belajar peserta didik sebaiknya disesuaikan dengan gaya pengajaran yang distrukturkan bagi siswa. Untuk memperoleh hasil yang efektif dalam proses pembelajaran maka digunakan berbagai macam metode mengajar agar menunjukkan hasil yang diharapkan. Salah satunya hal yang dapat dilakukan oleh guru secara individual dalam proses pembelajaran yaitu pemahaman terhadap gaya belajar siswa.

Guru yng mengetahui gaya belajar siswa yang berbeda akan membantu para guru dalam mengajar sehingga aktivitas belajar dapat tercapai sesuai dengan tujuan yang diinginkan. Dengan demikian, gaya belajar siswa harus dipahami oleh guru. Adapun salah satu gaya belajar siswa untuk memahami informasi yaitu gaya belajar kinestetik siswa yang mengharuskan individu yang bersangkutan menyentuh sesuatu yang memberikan informasi tertentu agar bisa mengingatnya.

Berdasarkan uraian tersebut, maka dalam proses belajar mengajar menguatamakan indera perasa dan gerakan fisik. Siswa dengan gaya kinestetik lebih mudah menangkap pelajaran apabila siswa bergerak, meraba, atau mengambil tindakan.

Analisis regresi sederhana gaya belajar kinestetik siswa terhadap hasil belajar pendidikan agama Islam memiliki pengaruh berdasarkan koefisien $\mathrm{R}^{2}$ (R Square) sebesar 0,105 atau 10,5\% yang menunjukkan bahwa pengaruh signifikan antara aspek gaya belajar kinestetik siswa dan hasil belajar pendidikan agama Islam dapat digunakan karena memiliki pengaruh terutama pada hasil belajar siswa. Berikut ini adalah tabel hasil angket gaya belajar kinestetik siswa untuk dijadikan acuan dalam mengklasifikasi tingkat persentase yang diperoleh siswa yang belajar dengan gaya kinestetik di kelas $\mathrm{X}\left(\mathrm{X}_{7} \& \mathrm{X}_{8}\right)$ SMA Negeri 4 Palopo. 
Jika skor gaya belajar kinestetik siswa dikelompokkan kedalam empat kategori maka diperoleh tabel distribusi frekuensi dan persentase gaya belajar kinestetik siswa sebagai berikut:

Tabel 4.18 Perolehan Persentase Kategorisasi Gaya Belajar Kinestetik Siswa

\begin{tabular}{|l|l|c|c|}
\hline \multicolumn{1}{|c|}{ Skor } & \multicolumn{1}{|c|}{ Kategori } & Frekuensi & Persentase (\%) \\
\hline $51-60$ & Kurang Baik & 11 & $22 \%$ \\
$61-70$ & Cukup Baik & 10 & $20 \%$ \\
$71-80$ & Baik & 14 & $27 \%$ \\
$81-90$ & Sangat Baik & 16 & $31 \%$ \\
\hline \multicolumn{2}{|r|}{ Jumlah } & 51 & $100 \%$ \\
\hline
\end{tabular}

Sumber: Hasil analisis data angket penelitian yang diolah, Tahun 2017

Prefensi sensori atau kemampuan yang dimiliki otak dalam menyerap, mengelola dan menyampaikan informasi bergantung pada gaya belajar siswa baik secara visual, auditorial dan kinestetik sehingga guru sebagai pengelola pembelajaran patut memperhatikan metode yanbg digunakan dalam mengajar agar siswa yang ditandai dengan ciri-ciri perilaku tertentu dalam menyerap informasi mampu menyesuaikan diri.

Pengkategorian karakteristik gaya belajar dijadikan pedoman bagi guru agar siswa mendapatkan rangsangan yang sesuai dalam belajar sehingga akan memudahkannya untuk menyerap pelajaran. Dengan kata lain jika siswa menemukan metode belajar yang sesuai dengan karakteristik gaya belajar siswa maka siswa akan cepat memahami. Berdasarkan uraian hasil penelitian yang telah dikemukakan maka dapat disimpulkan bahwa gaya belajar siswa kelas $\mathrm{X}\left(\mathrm{X}_{7} \& \mathrm{X}_{8}\right)$ SMA Negeri 4 Palopo yang memiliki pengaruh tertinggi terhadap hasil belajar siswa yaitu gaya belajar visual sebesar 13,2\%.

Pengaruh yang diperoleh berdasarkan gaya belajar siswa tersebut masih termasuk kurang ketika guru sebagai pengelola pembelajaran hanya memfokuskan proses pembelajaran dengan hanya mengarah pada satu aspek gaya belajar yang mendukung siswa dalam memahami pembelajaran. Oleh karena itu, berdasarkan hasil penelitian maka dalam pembelajaran sebaiknya guru mengkondisikan suasana belajar dengan memperhatikan gaya belajar siswa dalam menyerap informasi yang diberikan oleh guru. Berikut adalah hasil pengolahan data berdasarkan perolehan angket yang mengabungkan tiga gaya belajar siswa yaitu gaya belajar visual, auditori dan kinestetik terhadap hasil belajar siswa. 
Tabel 4.19 Koefisien perolehan nilai determinan gaya belajar visual, auditori, dan kinestetik siswa secara bersama terhadap hasil belajar pendidikan agama Islam di kelas X SMA Negeri 4 Palopo

Model Summaryb

\begin{tabular}{|c|c|c|c|c|c|c|c|c|c|}
\hline \multirow[t]{2}{*}{ Model } & \multirow[t]{2}{*}{$\mathrm{R}$} & \multirow{2}{*}{$\begin{array}{c}\mathrm{R} \\
\text { Squar } \\
\mathrm{e}\end{array}$} & \multirow{2}{*}{$\begin{array}{l}\text { Adjusted } \\
\text { R Square }\end{array}$} & \multirow{2}{*}{$\begin{array}{c}\text { Std. } \\
\text { Error of } \\
\text { the } \\
\text { Estimate }\end{array}$} & \multicolumn{5}{|c|}{ Change Statistics } \\
\hline & & & & & $\begin{array}{c}\text { R Square } \\
\text { Change }\end{array}$ & $\begin{array}{c}\text { F } \\
\text { Chang } \\
\text { e }\end{array}$ & $\begin{array}{c}\mathrm{df} \\
1\end{array}$ & $\begin{array}{l}\mathrm{df} \\
2\end{array}$ & $\begin{array}{c}\text { Sig. F } \\
\text { Chang } \\
\text { e }\end{array}$ \\
\hline 1 & $.211^{\mathrm{a}}$ & .360 & -.017 & $\begin{array}{r}14.5392 \\
7\end{array}$ & .044 & .728 & 3 & 47 & .541 \\
\hline
\end{tabular}

a. Predictors: (Constant), Gaya belajar kinestetik, Gaya belajar auditori , Gaya belajar visual

b. Dependent Variable: Hasil belajar PAI

Dengan demikian, peneliti menyimpulkan bahwa proses pembelajaran yang memperhatikan berbagai gaya belajar siswa akan lebih besar pengaruhnya untuk menintgkatkan hail belajar siswa.

\section{Hasil belajar siswa pendidikan agama Islam}

Setiap guru memiliki keinginan agar dapat meningkatkan hasil belajar siswa yang dibimbingnya termasuk guru pada mata pelajaran pendidikan agama Islam. Oleh karena itu, guru harus memiliki hubungan baik dengan siswa yang dapat terjadi melalui proses belajar mengajar. Setiap proses belajar mengajar keberhasilannya diukur dari seberapa jauh hasil belajar yang dicapai siswa.

Hasil belajar merupakan indikator dari perubahan yang terjadi pada individu setelah mengalami proses belajar mengajar, dimana untuk mengungkapkannya menggunakan suatu alat penilaian yang disusun oleh guru,seperti tes evaluasi. Hal ini dimaksudkan untuk mengetahui sejauh mana siswa tersebut memahami dan mengrti pelajaran yang diberikan. Hasil belajar juga merupakan prestasi yang dicapai oleh siswa dalam bidang studi tertentu untuk memperolehnya menggunakan standar sebagai pengukuran keberhasialn seseorang. Criteria hasil belajar pada siswa yang lazim digunakan adalah nilai rata-rata yang didapat melalui proses belajar.

Hasil belajar adalah pernyataan kemampuan siswa dalam menguasai sebagian atau seluruh kompetensi tertentu. Kompetensi adalah kemampuan yang dimiliki berupa pengetahuan, keterampilan, sikap dan nilai yang direfleksikan dalam kebiasaan bertindak dan berpikir setelah siswa menyelesaikan suatu aspek atau sub aspek mata pelajaran tertentu termasuk pendidikan agama Islam. Berikut ini adalah tabel hasil belajar pendidikan agama Islam yang diperoleh melalui tes evaluasi formatif ( ujian akhir semester) untuk dijadikan acuan dalam mengklasifikasi tingkat persentase 
hasil belajar pendidikan agama Islam yang diperoleh siswa di kelas $\mathrm{X}_{\left(\mathrm{X}_{7}\right.}$ \& $\left.\mathrm{X}_{8}\right)$ SMA Negeri 4 Palopo.

Jika skor hasil belajar pendidikan agama Islam dikelompokkan kedalam lima kategori maka diperoleh tabel distribusi frekuensi dan persentase hasil belajar pendidikan agama Islam sebagai berikut:

Tabel 4.21 Perolehan Persentase Kategorisasi Hasil Belajar PAI

\begin{tabular}{|l|l|c|c|}
\hline \multicolumn{1}{|c|}{ Skor } & \multicolumn{1}{|c|}{ Kategori } & Frekuensi & Persentase (\%) \\
\hline $50-59$ & Sangat Kurang & 5 & $10 \%$ \\
$60-69$ & Kurang Baik & 4 & $8 \%$ \\
$70-79$ & Cukup Baik & 8 & $15 \%$ \\
$80-89$ & Baik & 28 & $55 \%$ \\
$90-99$ & Sangat Baik & 6 & $12 \%$ \\
\hline \multicolumn{2}{|r|}{ Jumlah } & 51 & $100 \%$ \\
\hline
\end{tabular}

Sumber: Hasil analisis data angket penelitian yang diolah, Tahun 2017

\section{Penutup}

Gaya belajar siswa SMA Negeri 4 Palopo yang memiliki pengaruh tertinggi terhadap hasil belajar siswa yaitu gaya belajar visual sebesar 13,2\%. Gaya belajar siswa tersebut masih termasuk kurang ketika guru sebagai pengelola pembelajaran hanya memfokuskan proses pembelajaran dengan hanya mengarah pada satu aspek gaya belajar yang mendukung siswa dalam memahami pembelajaran. Selain itu, ada pengaruh antara aspek gaya belajar siswa terhadap hasil belajar pendidikan agama Islam didukung oleh koefisien $\mathrm{R}^{2}$ (R Square) sebesar 0,360 . Hal ini berarti bahwa 36\% aspek-aspek gaya belajar visual, auditori,dan kinestetik siswa ada pengaruh signifikan terhadap hasil belajar pendidikan agama Islam.

\section{Daftar Pustaka}

Ahmadi Abu dan Supriyono Widodo, Psikologi Belajar, Jakarta: Rineka Cipta, 2008.

Arikunto Suharsimi, Prosedur Penelitian: Suatu Pendekatan Praktik, Yogyakarta: Rineka Cipta, 2010.

Arifin, Penelitian Pendidikan: Pendekatan Kuantitatif dan Kualitatif, Yogyakarta: Lilin Persada Press, 2010.

Astuti Noer Endah Pengaruh Gaya Belajar Siswa Terhadap Prestasi Belajar Siswa Pada Mata Pelajaran Pendidikan Islam di SDN Karanggayam 02 Srengat Blitar Tahun 2014.

Departemen Agama, Al-Qur'an dan Terjemahnya, Jakarta: Redboy Indonesia, 2010. 
DePorter Bobby dan Hernacki Mike, terjemah Abdurrahman Alwiyah, Quantum Learning Membiasakan Belajar Nyaman dan Menyenangkan, Bandung: Kaifa PT Mizan Pustaka, 2005.

Dimyati dan Mudijono, Belajar dan Pembelajaran, Jakarta: Rineka Cipta, 2009.

D. Parson Richard, et.all. Educational Psychology: A Practitioner Approach, Singapore: Seng Lee Press, 2001.

Dwi Prasetya, Fajar, Gaya belajar peserta didik berprestasi akademik kelas IV SD Negeri Sumberreji Magelang Jawa Tengah Tahun 2013

Emirina, Gaya Belajar pada Anak. (http://emirina.wordpress.com. Diakses 11 Nopember 2016).

Gunawan Adi W., Genius Learning Strategy: Petunjuk Praktis untuk Menerapkan Accelarated Learning Jakarta: Gramedia Pustaka Utama, 2003.

Hariyanto dan Suyono, Belajar dan Pembelajaran. Bandung: Rmaja Rosdakarya, 2012.

Iskandar, Psikologi Pendidikan, Ciputat: Gaung Persada Press, 2009.

Iqbal Hasan, M., Pokok-pokok Materi Statistik 2, cet-4, Jakarta: Bumi Aksara, 2008.

Linksman Ricki, Cara Belajar Cepat, Semarang: Dahara Prize, 2008.

Mahbub M., Korelasi antara Kebiasaan Belajar dan Prestasi Belajar Siswa SMP Negeri 02 Longikis tahun pelajaran, (http://one.indoskripsi.com, diakses 09 Nopember 2016).

Nana Sudjana, Penilaian Hasil Belajar Mengajar, Bandung: Remaja Rosdakarya, 2012.

Nata, Abudin , Sosiologi Pendidikan Islam,Jakarta : RajaGrafindo Persada,2014

Subini Nini, Mengatasi Kesulitan Belajar pada Anak, Yogyakarta: Javalitera, 2012

Sukmadinata Nana Syaodih, Landasan Psikologi Proses Pendidikan, Bandung: Remaja Rosdakarya, 2013.

Sumanto Wasty, Psikologi Pendidikan, Jakarta: Rineka Cipta, 1990.

Sugiyono, Metode Penelitian Kuantitatif Kualitatif dan R\&D, Cet. 20; Bndung: Alfabeta, 2014

Suprayeki, Interaksi Belajar Mengajar, Jakarta: Direktorat Tenaga Kependidikan Dirjen Dikdasmen, Depdiknas, 2003.

Shota Farhan, Gaya Belajar Insan Pembelajar, (http://jendela-dunia.co.id. Diakses 10 November 2016)

Siregar, Syofian, Statistik Parametrik untuk Penelitian Kuantitatif, Jakarta: Bumi Aksara, 2014.

Sanafiah, Faisal Format-format Penelitian Sosial,Jakarta : Raja Grafindo Persada, 2005.

Slameto, Belajar dan Faktor-faktor yang Memepengaruhinya, Jakarta: Rineka Cipta 2005. 
Syah Muhibbin, Psikologi Pendidikan dengan Pendekatan Baru, Edisi Revisi, Bandung: Remaja Rosdakarya, 2002.

Steinbach Robert, succesfull Lifelong Learning, terjemah Kumala Insiswi Suryo, Jakarta: Victory jaya Abadi, 2012.

S. Suparman, Gaya Mengajar yang Menyenangkan Siswa, Yogyakarta: Pinud Book Publisher, 2010.

Sudijono, Anas , Pengatar Evaluasi Pendidikan, Jakarta: Raja Grafindo Persada, 2006.

Purwanto, Evaluasi Hasil Belajar, Yogyakarta: Pustaka belajar, 2010

Tohirin, PSikologoii Pembelajaran Pendidikan Agama Islam, Jakarta: Raja Grafindo, 2006.

Zuhud Muhammad, Strategi Guru Agama Islam Dalam Meningkatkan Minat Belajar Pendidikan Agama Islam Di SMP Negeri 1 Makale Kabupaten Tana Toraja, Jurusan Tarbiyah Program Studi Pendidikan Agama Islam tahun 2010. 